\title{
To the Question of an Ethics of Bible Translation: Some Reflections in Relation to Septuagint Isaiah 6:1 and 19:25
}

\author{
KNut Holter (VID SPECialized University, StaVANGER)
}

\begin{abstract}
The essay discusses two texts from Septuagint Isaiah-6:1 and 19:25in dialogue with some concerns of recent discourses of Bible translation ethics. The main focus of the essay is the question of a translation's "loyalty" vis-à-vis source text, target language and culture, and other actors involved in the translation process. It is argued that the two case texts from Septuagint Isaiah offer different solutions; whereas 6:1 accentuates a concept already present in the Hebrew text, 19:25 thus offering a competing plot to that of the Hebrew text.
\end{abstract}

KEYWORDS: Ethics, Isaiah, loyalty, Septuagint, translation

In Bible translation studies and amongst Bible translation practitioners, the question of how to develop and formulate an ethics of the field is receiving increasing attention. In the following pages, I will reflect on some of the questions that are currently being raised, with two cases from the mother of all Bible translations, the Septuagint, as my textual dialogue partner. I will start with a brief survey of some recent contributions to the ethical discourse on Bible translation, then continue with a close reading of my two textual cases, both from Septuagint Isaiah, and finally relate the ancient cases to some of the questions of the current ethical discourse. ${ }^{1}$

\section{A SOME RECENT CONTRIBUTIONS TO THE ETHICAL DISCOURSE ON BIBLE TRANSLATION}

Questions of ethics have always followed translation of the Bible; the translators have been discussing the whys and hows of their endeavours, not only from a technical and hermeneutical perspective, but also with attention to the ethical questions that emerge in the translation process. Following the twentieth

* Submitted: 14/09/2018; peer-reviewed: 29/10/2018; accepted: 27/11/2018. Knut Holter, "To the Question of an Ethics of Bible Translation: Some Reflections in Relation to Septuagint Isaiah 6:1 and 19:25," Old Testament Essays 31 no. 3 (2018): 651-662. https://doi.org/10. 17159/2312-3621/2018/v31n3a14.

1 It is a privilege to dedicate the following pages on Septuagint Isaiah and the question of an ethics of Bible translation to Professor Willie Wessels, a colleague and friend at the University of South Africa, whose research merits include insightful contributions to the study of the prophetic corpus of the Old Testament. 
century's establishing of Bible translation as an academic field, one should not be surprised to see that ethical questions are currently receiving increasing attention. During the last decade, several scholars - and many of them are also practitioners in the field - have argued that we need a kind of "code of ethics" for Bible translation. Let me exemplify their concern with a brief presentation of three contributors to the discourse.

A first example is provided by Steven M. Voth, a North American biblical scholar and translation coordinator within the United Bible Societies. In two essays from 2008, he makes some suggestions "towards" an ethic of Bible translation, with examples from his own experiences in South America as textual background. ${ }^{2}$ It is important to him that it is an ethic, not the ethic, as Bible translation is too complex to be covered by one overall perspective, he argues. Consequently, he narrows the question down to two ethical perspectives, the roles of ideology and marketing in the translation and publishing processes. Ideology, because no translation is "neutral," and that it therefore is important to realize and relate constructively to the translator's biases. And marketing, because the "market" - which differs tremendously from one context to another, not least related to the question of whether the language has other Bible translations - and the possibilities to have the translation distributed and sold inevitably play central roles also when it comes to the ethical reflections of the translator and translation project. In conclusion, Voth argues that a Bible translation ethic must place human needs at the centre, so that it may have an overall liberating function.

Another example comes from Krijn van der Jagt, a Dutch translation consultant within the United Bible Societies. In a 2010 essay, he voices two ethical concerns, viz. one is what a legitimate translation of ancient biblical texts may be, and the other is what kind of implications it has to publish ancient biblical texts, reflecting an ancient worldview, into our time. ${ }^{3}$ Discussing the question of a "legitimate" translation, he leans towards Derrida, who perceives translation not as a reproduction of the meaning of a source text, but as something new. And, more generally, he emphasizes the need for an awareness of norms and values. When it comes to the implications of publishing ancient biblical texts today, he acknowledges the problems, and argues that the translator should be

2 Steven M. Voth, "Towards an ethic of liberation for Bible translation. Part 1: Ideology," SBL Forum, 6/2 (2008), https://www.sbl-site.org/publications/article. aspx?ArticleId=774, accessed 2018-08-25; and Steven M. Voth, "Towards an ethic of liberation for Bible translation. Part 2: Marketing," SBL Forum 6/5 (2008). https://www.sbl-site.org/publications/article.aspx?ArticleId=774, accessed 2018-0825.

3 Krijn Van der Jagt, "Ethical concerns and worldview perspectives in Bible translation: An inquiry into the ethics of Bible translation," BT 61/3 (2010): 101-122. 
comprehended as a mediator between the cultural world of the Bible and the culture of today's global village.

A third example comes from Eberhard Werner, a German translation coordinator working within the Wycliffe / SIL movement. In an essay from 2014, he suggests some guidelines "toward"-like Voth-a code of ethics in Bible translation. However, he is more concrete than Voth, and he is also more optimistic about finding common ideals. Hence, he gives attention to a number of practical issues, but in particular he emphasizes more ideological perspectives, such as the sacredness of the Bible and translation as a ministry of the church. ${ }^{4}$ Some of the practical issues are also addressed in a 2012 essay on an ethical code in Bible translation consulting, where he points out the multiple pressure experiences the translation consultant is exposed to. ${ }^{5}$

There are a number of parallel perspectives in the three examples. However, preparing for the coming discussion of two texts from Septuagint Isaiah, I will emphasize one particular perspective that goes through all three, namely that of loyalty. As a technical term, it is in particular used within functional translation approaches,${ }^{6}$ but in a broader sense it is commonly used about being faithful to the involved actors: the biblical text, the target culture and language, but also the wider constituencies of Bible translation, interpretation and use, in church and society. Voth notices that "[...] many 'loyalties' come into play: loyalty to the Old Testament, loyalty to the New Testament, loyalty to translation tradition, loyalty to the sponsoring society, and loyalty to the consumer, among others." 7 Van der Jagt uses the word pair "loyal" and "loyalty" similarly, vis-à-vis "[...] the original writer, the commissioner of the translation, the translator himself or herself, the prospective readership, and other relevant parties." And Werner is also concerned about the question of loyalty, even mentioning it in connection with a suggestion of introducing a kind of Hieronymic oath of translators. ${ }^{9}$

However, loyalty is also a quite problematic perspective, as expectations of loyalty often come from mutually opposing directions. An illustrative example

4 Eberhard Werner, "Toward a code of ethics in Bible translation," JT 10/1 (2014): 15-23.

5 Eberhard Werner, "Toward an ethical code in Bible translation consulting," JT 8/1 (2012): 1-8.

6 Cristiane Nord, "Lojalität als ethisches Verhalten im Translationsprozess," in Und sie bewägt sich doch .... Translationswissenschaft in Ost und West: Festschrift für Heidemarie Salevsky zum 60 Geburtstag, ed. Ina Müller (Frankfurt a.M: Peter Lang, 2004), 234-245.

7 Voth, "Towards an ethic: Part 1."

8 Van der Jagt, "Ethical concerns," 104.

9 Werner, "Towards an ethical code." 
of this is provided by Anne Lise Matre, ${ }^{10}$ a Norwegian translator operating in Mali. She responds to some reflections John S. Mbiti made after he had completed translating the New Testament into his Kenyan vernacular, Kiikamba. ${ }^{11}$ Mbiti reflects on controversial terms like "rule" vs "shepherd" in Revelation 2-3, and "Jews" vs "Jewish leaders" in John, arguing-quite convincingly in my view - that one should avoid terms that have previously proved offensive. In spite of this, Matre criticizes Mbiti for paying too much attention to the context of the audience, at the cost of the biblical co-texts. The translation, she argues, should have a particular loyalty to the source text.

So, the balance tips over to the textual context again. And there we are. Let us therefore now turn to some textual cases from the Septuagint, the classical translation of the Old Testament into Greek, with the ambiguous question of loyalty as a guide.

\section{B CLOSE READING OF TWO CASES FROM SEPTUAGINT ISAIAH}

Septuagint Isaiah has received much attention in recent years, from literary and historical perspectives, attempting to trace the development and characteristics of the text, ${ }^{12}$ but also from more hermeneutical perspectives. ${ }^{13}$ I will focus on two cases of Septuagint Isaiah's translation of the Hebrew text. ${ }^{14}$ The first case

\footnotetext{
10 Anne Lise Matre, "To which context is a translator responsible? A response to John S. Mbiti," BT 63 (2012): 197-206.

11 John S. Mbiti, "Challenges of language, culture and interpretation in translating the New Testament," STT 97 (2009): 141-164.

12 A classical study is that of Isac L. Seeligmann, The Septuagint Version of Isaiah: A Discussion of its Problems. Leiden: Brill, 1948; of more recent studies, see especially Arie van der Kooij, Die alten Textzeugen des Jesajabuches: Ein Beitrag zur Textgeschichte des alten Testaments. Orbis Biblicus et Orientalis 35 (Freiburg: Universitätsverlag Freiburg, 1981); Arie van der Kooij \& Michaël N. van der Meer, eds. The Greek of Isaiah: Issues and Perspectives. Papers Read at the Conference on the Septuagint of Isaiah, Held in Leiden 10-11 April 2008. Contributions to Biblical Exegesis and Theology 55 (Leuven: Peeters, 2010); Seulgi L. Byun, The Influence of Post-Biblical Hebrew and Aramaic on the Translator of Septuagint Isaiah. Library of Hebrew Bible / Old Testament Studies 635 (London: T\&T Clark, 2017).

13 See especially Ronald L. Troxel, LXX-Isaiah as Translation and Interpretation: The Strategies of the Translator of the Septuagint of Isaiah. Supplements to the Journal for the Study of Judaism 124 (Leiden: Brill, 2008); J. Ross Wagner, Reading the Sealed Book: Old Greek Isaiah and the Problem of Septuagint Hermeneutics. Waco: Baylor University Press, 2014; Mirjam van der Vorm-Crough, The Old Greek of Isaiah: An Analysis of its Pluses and Minuses. Septuagint and Cognate Studies 61 (Atlanta: SBL Press, 2014).

14 I acknowledge the anachronistic problems of talking about "the Hebrew text" as an identifiable text being available to the Septuagint translators. Still, for pragmatic
} 
is found in 6:1, where the Hebrew phrase ושוליו מלאים את־ההיכל, "and the train of

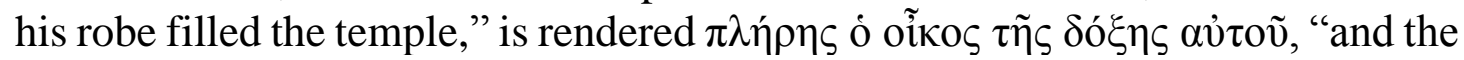
house was full of his glory." This is a classical case, often referred to as an example of a cultural adjustment from the side of the Septuagint translators. The problem here, most exegetes tend to argue, is not that the translators did not understand what the Hebrew term שול means; it is translated more accurately in Exodus 28:34 and 39:24-26. Rather, the problem is that the translators actually understood the Hebrew term quite well, but did not like what they saw: a depicting of the Lord in the likeness of an ancient Near Eastern king, with a "throne" (which could be accepted, due to its metaphorical potential) but then also with a "robe" (which was more difficult to accept, due to its anthropomorphic tenor). It is symptomatic of the exegetical tradition that the critical apparatus in Biblia Hebraica Stuttgartensia not even mentions this case; it is simply not a "text critical" problem, it is - in the words of Hans Wildberger _ "dogmatische Korrektur des ihr unerträglichen Antromorphismus."15

Nevertheless, the translator's decision to replace שול with $\delta$ ' $\xi \alpha$ touches some interesting translational questions. Septuagint Isaiah has a particular preference for the term $\delta$ ó $\xi \alpha,{ }^{16}$ and its introduction here in v. $1 \mathrm{~b}$ fits well into the immediate literary context. The term reoccurs already in v. $3 \mathrm{~b}$, in the trisagion of the Seraphs, there as the expected translation of the Hebrew text's כבוד, "glory." Moreover, the introduction of $\delta$ ó $\xi \alpha$ in v. 1 b not only anticipates the same term two verses later, it actually also enables the translators to construct vv. $1 \mathrm{~b}$ and $3 \mathrm{~b}$ as parallels:

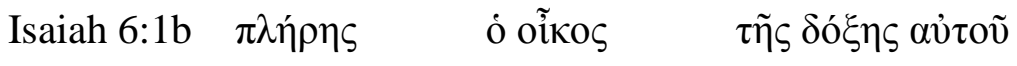

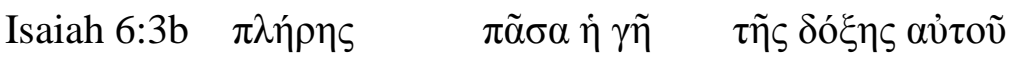

This parallel structure creates a beautiful play on terminology, rhythm, and sound. Also, it clarifies - or perhaps, again: creates - a connection between v. 1b's "house" and v. 3b's "whole earth." A rhetorical connection between vv. $1 b$ and $3 b$ is indicated in the Hebrew text by the repetition of the key verb מלא (vv. 1 and 3, also to be repeated in v. 4). However, the connection is sharpened by the parallel structure of the Septuagint version, with its more dynamic conceptualization of the Lord's "glory;" moving from the "house" - presumably the temple in Jerusalem - to the "whole earth." Taking into account the

reasons and with special regard to my two textual cases (Isaiah 6:1 and 19:25), I use the term "the Hebrew text" about texts we know from the Masoretic tradition (cf. Biblia Hebraica Stuttgartensia and Hebrew University Bible Project: Book of Isaiah), though in comparison also with Isaiah material from Qumran.

15 Hans Wildberger, Jesaja 1-12. Biblischer Kommentar Altes Testament X/1 (Neukirkchen-Vluyn: Neukirchener Verlag, 1980, 2. rev. ed.), 232.

16 L.H. Brockington, "The Greek translator of Isaiah and his interest in $\delta$ ó $\xi \alpha$," VT 1 (1951): 23-32. 
terminological connection between Isaiah 6 and 40:1-11, ${ }^{17}$ one could argue that the reference to the Lord's $\delta$ ó $\xi \alpha$ in Isaiah 40:5, envisioning that all people will see $\dot{\eta} \delta$ ó $\xi \alpha$ Kvpíov, "the glory of the Lord," is a relevant parallel to the move from "house" to "whole earth" in Septuagint Isaiah 6:1 and 3.

My second case is found in Isaiah 19:25, the vision of peace - at least in ברוך : the Hebrew version of the text—between Israel and her mighty neighbours בעמי מצרים ומעשה ידי אשור ונחלתי ישראל handiwork, and Israel my inheritance." The Septuagint here offers a rendering that is terminologically quite close to the Hebrew text, but where the overall plot

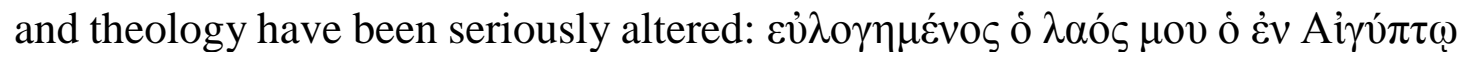

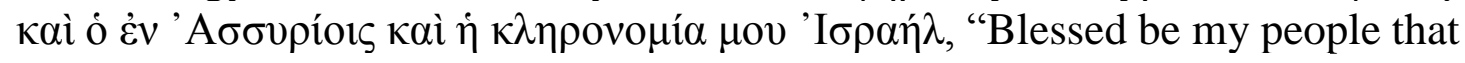
is in Egypt, and that is among the Assyrians, and Israel my inheritance." Instead of seeing Egypt and Assyria as peace partners of Israel-like the Hebrew rendering of the text, with terms like עמי, "my people" and "my ידהי, "my handiwork," both normally expressing the particular role of Israel, such as for example in Isaiah 64:7-8 - the Septuagint transfers the focus from these two neighbouring peoples to the Jewish diaspora communities in the two countries.

Egypt, more than Assyria, is the key focus of Isaiah 19, and in its Hebrew version it offers a portrayal of Egypt that includes quite ambivalent scenes; there is judgment but also salvation, and the tension between the two can be seen from macro (vv. 1-17 vs 18-25) but also micro (v. 22: "strike" vs "heal") perspectives. In this context of ambivalence, the vision of peace in v. 25 does not come out of the blue, it is prepared in the preceding verses. Most explicitly in vv. 23-24, which anticipate v. 25 by pointing out a "highway" from Egypt to Assyria, allowing the two to worship together (v. 23) and hence, together with Israel, being a blessing on the earth (v. 24). Also, to some extent, in vv. 18-22, with references to an alter to the Lord in the midst of Egypt (v. 19), and to the Egyptians worshipping the Lord with sacrifices and grain offerings (v. 21), and even to the Egyptians turning to the Lord to be healed (v. 22). It should here be emphasized that the portrayal of Egypt throughout Hebrew Isaiah 19-an Egypt experiencing judgment as well as salvation-is that of a real Egypt, not "Egypt" as a hidden reference to something else; it is a people experiencing that the Nile dries up, so that the fishermen suffer (vv. 7-8), and it is a country with canals and streams (v. 6), with cities (vv. 13 and 18), borders (v. 19), and neighbouring countries (v. 24-25).

However, when Septuagint Isaiah 19:25 replaces "Egypt my people" with "my people in Egypt," this reading, too, is to some extent prepared in the preceding verses in that the Septuagint version of Isaiah 19 creates a tension between real Egypt and the Jewish diaspora community "in Egypt." One example is found in v. 23, which, in the words of John F.A. Sawyer, has an "[...]

17 Knut Holter, “Zur Funktion der Städte Judas in Jes xl 9,” VT 46 (1996): 119-121. 
unmistakeable anti-Egyptian slant at the end of the verse."18 Whereas most modern interpreters read the particle את in this verse as a preposition, "with," and interpret the verb עבד in a cultic sense ("the Egyptians and Assyrians will worship together"), the Septuagint (and other ancient versions) takes the את as a nota accusativi and interprets עבד in a political sense. The Septuagint then gets: кai

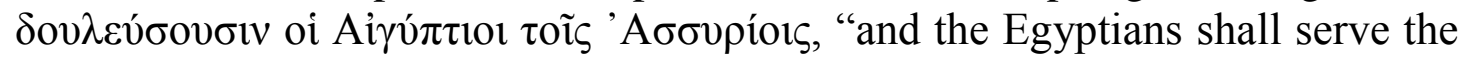
Assyrians," that is a reading that weakens the paralleling of Egypt and Assyria with Israel in v. 25. Another example that fits into a tension in Isaiah 19 between real Egypt and the Jewish diaspora community in Egypt is the reference to an "alter for the Lord" in v. 19. This reference was in the first century BCE read in relation to the Jewish diaspora community "in Egypt," as can be seen in Josephus' reference to an initiative to build a temple in Egypt, "similar to that at Jerusalem," encouraged "by the words of the prophet Isaiah" (Josephus, Antiquitatis, xiii,62-67).

\section{ANCIENT CASES AND CURRENT ETHICAL DISCOURSE}

As I pointed out above, the question of loyalty is a key term in contemporary discourses on ethics of Bible translation. However, it is a rather problematic term, immediately raising questions about loyalty to whom and to what degree. The term loyalty itself tends to expect an either/or; either loyalty to the culture and language of the "source" or to the corresponding ones of the "target." But so is of course never the case, a translation will always be negotiating loyalty in both directions.

As far as the case of $\delta$ ó $\xi \alpha$ versus שול in Isaiah 6:1 is concerned, there is a quite general consensus amongst interpreters that the Septuagint version here reflects an anti-anthropomorphic tendency. ${ }^{19}$ And I agree. It seems clear that Septuagint Isaiah as a whole is characterized by a reduction of the number of anthropomorphisms; ${ }^{20}$ one illustrative example is found in a text I referred to above as a parallel to Isaiah 6:3, namely Isaiah 40:5, where the Hebrew "for the mouth of the Lord has spoken," is translated "for the Lord has spoken," by the Septuagint.

Contemporary translation projects, too, are able to come up with parallel cases. One example is the Living Bible, a version which purposely paraphrases and explains the text. In Isaiah 6:1, it actually reads "the Temple was filled with his glory," though without any explanatory footnote, so one has to guess why it

18 John F.A. Sawyer, “'Blessed be my people Egypt' (Isaiah 19.25): The context and meaning of a remarkable passage," in A Word in Season: Essays in Honour of William McKane (Journal for the Study of the Old Testament Supplement Series 42, ed. James D. Martin \& Philip R. Davies; Sheffield: JSOT Press, 1986]), 64.

19 Troxel, LXX-Isaiah, 128-130.

20 Van der Vorm-Croughs, The Old Greek, 464-468. 
ends up like the Septuagint. My guess would be that it reflects a similar wish as that of the Septuagint to avoid anthropomorphisms that are not deemed necessary. A similar tendency is also reflected elsewhere in its version of Isaiah, again for example in 40:5.

Another example, where we actually do have access to a reflection from the translator's side, is referred to by Steven M. Voth, who served as a translation consultant with an Old Testament project in a community in northern Argentina. At the time of the translation of the Old Testament, the New Testament had already been translated and it had caused a development of a theology of a benevolent God. Now, as the Old Testament was being translated, with texts depicting God as jealous and angry, a local chief and mother tongue translator told the translation consultant that these concepts were unacceptable for the community. The chief refused to translate adjectives describing God in morally problematic ways, as it would diminish God and cause that God's reputation would suffer in the community. ${ }^{21}$

Voth's report is interesting because it allows some critical reflections from the side of a target community to be verbalized. Far from being passive recipients, they - as part of the translation process-engage in a critical discourse about key theological questions and their consequences for the translation of the Bible. However, Voth's report is also interesting as it illustrates some of the ethical dilemmas of the translation consultant: again it is the question of loyalty, but to whom, and to what degree? Eberhard Werner touches this dilemma, and argues that we need an ethical code not only in Bible translation in general, but also in the more specialized genre of Bible translation consulting: "To whom are consultants responsible? Is it to the initiating institution or organization, to the individual's or a people group's conscience, to God, to the translation team, or to the translation project?"22 Voth realizes that the question of loyalty, not least with regard to the translation consultant, also includes aspects of power. The scholarly background and organizational roles of the translation consultants give them a strong institutional power, and they may be tempted to let their scholarly based loyalty overrule the resistance from someone like this local chief. However, the local chief is de facto stronger; if he does not approve the translation, no one in the community will read it. Hence Voth's rhetorical question: "Do we want the text to be read by the community?" 23

However, even if a culturally based anti-anthropomorphism is accepted as the explanation of the choice of $\delta$ ó $\xi \alpha$ in Septuagint Isaiah $6: 1$, this does not mean that we here have a translation where the question of loyalty has been negotiated only in the direction of target culture and language. The decision to

21 Voth, "Towards an ethic: Part 1."

22 Werner, "Toward an ethical code," 1.

23 Voth, "Towards an ethic: Part 1." 
replace the שול of the Hebrew v. 1 with $\delta$ ó $\xi \alpha$ does not introduce anything new in the text. The $\delta$ ó $\xi \alpha$ is well integrated into the passage, recurring two verses later and also enabling the translators to construct vv. $1 \mathrm{~b}$ and $3 \mathrm{~b}$ as parallels. The translators can therefore hardly be said to have altered the text in any significant way or added anything to the text, at most they have reduced the text's interpretive potential slightly.

Quite different is the situation in the Septuagint version of Isaiah 19:25. Scholars generally explain the tension between the Hebrew עמי מצרים, "my

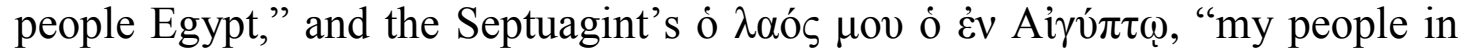
Egypt," as a result of a new interpretive context. Now, the dating of this Hebrew text is debated, and some scholars have given it a very late dating, into the second century BCE. Nevertheless, even in its present form, the Hebrew version of Isaiah 19:25 is most probably older than the Septuagint version, perhaps dating back to exilic or early post-exilic times. ${ }^{24}$ The Septuagint version is easier to date, most probably dating back to the second century BCE and located to Alexandria. Hence, the Septuagint version reflects experiences and concerns of the Jewish diaspora community in Ptolemaic Egypt.

The question of translation loyalty is quite complex here in 19:25. On the one hand, one could argue that the translators are loyal to the terminology of the source text, as the changes of the translation compared to the source text are terminologically very minor. In the case of v. 25, only an introduction (twice) of the one-letter preposition ב, "in," is needed in the Hebrew text to justify the Septuagint version, and in v. 23, no changes at all are necessary in the Hebrew text to end up with the Septuagint rendering; both the assumption that the particle

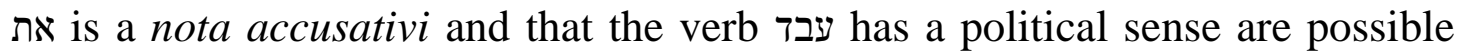
interpretations. On the other hand, however, these minor terminological additions and interpretive preferences allow Septuagint Isaiah 19:25 to presentand be part of - a competing plot to that of the Hebrew text, reading the Jewish diaspora communities in Egypt and Assyria into the Isaiah text.

The Septuagint rendering of Isaiah 19:25 is discussed in Isac L. Seeligmann's classic analysis of Septuagint Isaiah, and he argues that the translator "[...] presumably regarded the diaspora in Egypt, to which he himself belonged, as the rightful recipient of the prophetically promised salvation." 25 Similar observations have been made by several later scholars, such as for example Ronald L. Troxel, who points to Septuagint Isaiah 11:16 as a parallel. ${ }^{26}$ Quite recently, Mirjam van der Vorm-Croughs has launched the expression

24 For a survey and discussion, cf. Sawyer, “"Blessed be my people Egypt," 56-71.

25 Seeligmann, Septuagint Version, 117.

26 Troxel, LXX-Isaiah, 157-158. 
"nationalistic attitude," arguing that such an attitude is reflected throughout Septuagint Isaiah, and referring to $19: 25$ as "the most obvious" example. ${ }^{27}$

However, rather than seeing the Septuagint version of Isaiah 19:25 as an example of a "nationalistic attitude," I will suggest that it could be comprehended as an attitude - or perhaps better: hermeneutics - of resistance. Postcolonial biblical studies have taught us to be aware of how biblical texts have been used to oppress and marginalize. As a critical approach it therefore seeks to expose how the dominated are represented by the dominants, ${ }^{28}$ and the history and practice of Bible translation offer many examples of how colonial concerns have entered the translations and led to a marginalization of vernacular concepts and values. $^{29}$

However, postcolonial biblical studies have also provided examples of how the Bible has served and even — constructively today — may serve as a tool for resistance against oppression and marginalization. An example is Oral Thomas' study of biblical resistance hermeneutics in the Caribbean, based on experiences of ordinary Bible readers who come from a tradition of slavery and oppression. Thomas argues that where biblical texts are approached out of a commitment to and involvement in a struggle for social change and justice, it may result in resistance to oppressive systems and practices. ${ }^{30}$ Insights such as those of Thomas and other postcolonial biblical thinkers, I think, may add a perspective to the interpretive context of Septuagint Isaiah and its version of 19:25. The Jewish community in the Ptolemaic kingdom was in spite of its relative size still a minority, and the Septuagint - as a major literary work of theirs - reflects this minority's constant negotiation with the overall political and cultural majority.

\section{CONCLUSION}

So, where should the loyalty be located? All through the translation process, of course. Still, as we are dealing with texts, there are certain limits of what can count as a translation, and the two cases discussed above may give some indications about these limits. On the one hand, in the case of Septuagint Isaiah

27 Van der Vorm-Croughs, The Old Greek, 463.

28 Let me here restrict myself to just referring to Stephen N. Moore \& Fernando F. Segovia, eds. Postcolonial Biblical Criticism: Interdisciplinary Intersections. The Bible and Postcolonialism (London: T\&T Clark International, 2005); also Rasiah S. Sugirtharajah, The Bible and Asia: From Pre-Christian Era to Postcolonial Age (Cambridge, Massachusetts: Harvard University Press, 2013).

29 For examples, see the many case studies in Musa W. Dube \& Robert S. Wafula, eds. Postcoloniality, Translation, and the Bible in Africa (Eugene: Pickwick, 2017), 207.

30 Thomas, Oral. Biblical Resistance Hermeneutics within a Caribbean Context (London: Routledge, 2010) (BibleWorld). 
6:1, the translators have - probably for good reasons - wanted to tone down the anthropomorphism of the Hebrew text, and they were able to do this by accentuating another term and concept that was already present in the text. On the other hand, in the case of 19:25, the translators have-here, too, probably for good reasons-wanted to make the text relevant into their particular sociocultural context. The problem, and it is an ethical problem, of the latter case is that the translators here in reality offer a competing plot to that of the Hebrew text. As such the result illustrates the old insight that all translation is interpretation, but not all interpretation is - at least good - translation.

\section{BIBLIOGRAPHY}

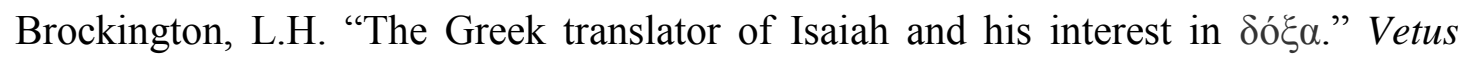
Testamentum 1 (1951): 23-32.

Byun, Seulgi L. The Influence of Post-Biblical Hebrew and Aramaic on the Translator of Septuagint Isaiah. Library of Hebrew Bible / Old Testament Studies 635. London: T\&T Clark, 2017.

Dube, Musa W. \& Robert S. Wafula, eds. Postcoloniality, Translation, and the Bible in Africa. Eugene: Pickwick, 2017.

Holter, Knut. "Zur Funktion der Städte Judas in Jes xl 9." Vetus Testamentum 46 (1996): 119-12. https://doi.org/10.1163/1568533962581116

Matre, Anne Lise. "To which context is a translator responsible? A response to John S. Mbiti." The Bible Translator 63 (2012): 197-206. https://doi.org/10.1177/026009351206300404

Mbiti, John S. "Challenges of language, culture and interpretation in translating the New Testament." Swedish Theological Themes 97 (2009): 141-164.

Moore, Stephen N. \& Fernando F. Segovia, eds. Postcolonial Biblical Criticism: Interdisciplinary Intersections. The Bible and Postcolonialism. London: T\&T Clark International, 2005.

Nord, Cristiane. "Lojalität als ethisches Verhalten im Translationsprozess." Pages 234245 in Und sie bewägt sich doch .... Translationswissenschaft in Ost und West: Festschrift für Heidemarie Salevsky zum 60 Geburtstag, ed. Ina Müller. Frankfurt a.M.: Peter Lang, 2004.

Sawyer, John F.A. "'Blessed be my people Egypt' (Isaiah 19.25): The context and meaning of a remarkable passage." Pages 56-71 in A Word in Season: Essays in Honour of William McKane. Journal for the Study of the Old Testament Supplement Series 42, ed. James D. Martin \& Philip R. Davies. Sheffield: JSOT Press, 1986.

Seeligmann, Isac L. The Septuagint Version of Isaiah: A Discussion of its Problems. Leiden: Brill, 1948.

Sugirtharajah, Rasiah S. The Bible and Asia: From Pre-Christian Era to Postcolonial Age. Cambridge, Massachusetts: Harvard University Press, 2013. https://doi.org/10.4159/harvard.9780674726468

Thomas, Oral. Biblical Resistance Hermeneutics within a Caribbean Context. BibleWorld. London: Routledge, 2010. 
662 Holter, "Ethics of Bible Translation," OTE 31/3 (2018): 651-662

Troxel, Ronald L. LXX-Isaiah as Translation and Interpretation: The Strategies of the Translator of the Septuagint of Isaiah. Supplements to the Journal for the Study of Judaism 124. Leiden: Brill, 2008.

Van der Jagt, Krijn. "Ethical concerns and worldview perspectives in Bible translation: An inquiry into the ethics of Bible translation." The Bible Translator 61 no. 3 (2010): 101-122. https://doi.org/10.1177/026009351006100301

Van der Kooij, Arie. Die alten Textzeugen des Jesajabuches: Ein Beitrag zur Textgeschichte des alten Testaments. Orbis Biblicus et Orientalis 35. Freiburg: Universitätsverlag Freiburg, 1981.

Van der Kooij, Arie \& Michaël N. van der Meer, eds. The Greek of Isaiah: Issues and Perspectives. Papers Read at the Conference on the Septuagint of Isaiah, Held in Leiden 10-11 April 2008. Contributions to Biblical Exegesis and Theology 55. Leuven: Peeters, 2010.

Van der Vorm-Croughs, Mirjam. The Old Greek of Isaiah: An Analysis of its Pluses and Minuses. Septuagint and Cognate Studies 61. Atlanta: SBL Press, 2014. https://doi.org/10.2307/j.ctt1287n57

Voth, Steven M. "Towards an ethic of liberation for Bible translation. Part 1: Ideology." SBL Forum, 6 no. 2 (2008). https://www.sblsite.org/publications/article.aspx?ArticleId=774, accessed 2018-08-25.

Voth, Steven M. "Towards an ethic of liberation for Bible translation. Part 2: Marketing." SBL Forum, 6 no. 5 (2008). https://www.sblsite.org/publications/article. aspx?ArticleId=774, accessed 2018-08-25.

Wagner, J. Ross. Reading the Sealed Book: Old Greek Isaiah and the Problem of Septuagint Hermeneutics. Waco: Baylor University Press, 2014.

Werner, Eberhard. "Toward an ethical code in Bible translation consulting." Journal of Translation 8 no. 1 (2012): 1-8.

Werner, Eberhard. "Toward a code of ethics in Bible translation." Journal of Translation 10 no. 1 (2014): 15-23.

Wildberger, Hans. Jesaja 1-12. Biblischer Kommentar Altes Testament, X/1. Neukirkchen-Vluyn: Neukirchener Verlag, 1980, 2. rev. ed.

Professor Knut Holter, Centre for Mission and Global Studies \& Faculty of Theology, Diaconia and Leadership Studies, VID Specialized University, Misjonsmarka 12, N-4024 Stavanger, Norway. Email: knut.holter@vid.no. ORCID ID: https://orcid.org/0000-0001-6467-3325. 